\title{
Vegetables Consumption Before Carbohydrates Improves Daily Fiber Intake and Blood Sugar Levels in Patients With Type 2 Diabetes Mellitus
}

\author{
* $1^{\text {st }}$ Dian Eka Widyasari \\ Postgraduate Program of Nutrition \\ Science \\ Universitas Sebelas Maret \\ Surakarta, Indonesia \\ diandhanial11@gmail.com
}

\author{
$2^{\text {nd }}$ Sugiarto \\ Postgraduate Program of Nutrition \\ Science \\ Universitas Sebelas Maret \\ Surakarta, Indonesia \\ giarto.sppd@yahoo.co.id
}

\author{
$3^{\text {rd }}$ Dono Indarto \\ Postgraduate Program of Nutrition \\ Science \\ Universitas Sebelas Maret \\ Surakarta, Indonesia \\ dono@staff.uns.ac.id
}

\begin{abstract}
Diabetes mellitus is one of non-communicable diseases that its prevalence increases significantly worldwide including in Indonesia. Nutrition therapy through food management is useful for improvement of the $\beta$-pancreas function in producing the insulin hormone. Changing food sequence of eating vegetables first and then carbohydrates and proteins may enhance fiber intake and improve blood sugar levels. The aim of this study was therefore to investigate the effects of vegetables consumption before carbohydrates on fiber intake and blood sugar levels. This study used randomized control trial compared the effects of eating vegetables first and then carbohydrates and proteins may enhance fiber intake and improve blood sugar levels. A number of 24 patients with type 2 diabetes mellitus and no complication who aged 18-65 years old. After 10 days treatment, the mean difference of fiber intake in the $\mathrm{T} 1$ group $(2.67 \pm 0.9 \mathrm{~g} /$ day $)$ was significantly higher than the mean differences of fiber intake in the $\mathrm{C}$ group $(-0.4 \pm 1.25 \mathrm{~g} / \mathrm{day} ; \mathrm{p}=$ $<0.001)$ and the $T 2$ group $(0.29 \pm 0.59 \mathrm{~g} / \mathrm{day} ; \mathrm{p}=<0.001)$. Meanwhile, a significant lower the mean difference of blood sugar levels was observed in the T1 group $(-48.00 \pm 23.96 \mathrm{~g} / \mathrm{dL})$, compared to the mean difference of blood sugar levels in the $\mathrm{C}$ group $(-9.25 \pm 32.15 \mathrm{~g} / \mathrm{dL} ; \mathrm{p}=\mathbf{0 . 0 1})$. Vegetables consumption before carbohydrate increases daily fiber intake and decreases blood sugar levels in patients with type 2 diabetes mellitus.
\end{abstract}

Keywords - vegetable consumption before carbohydrates, fiber intake, blood sugar levels, type 2 diabetes mellitus

\section{INTRODUCTION}

Diabetes mellitus is a non-communicable disease that has increased significantly in Indonesia during the last 10 years[1]. Chronic hyperglycemia in diabetes mellitus independently correlated with organ dysfunctions and damage, often resulting in failure of many human body organs [2]. Diabetes mellitus management aims to control blood sugar levels and prevent further complications that result in organ failure, through the application of four pillars namely education, diet therapy, physical activity, and pharmacological therapy[3].

Diet therapy is one of the pillars that support the successful control of blood sugar levels. Eating fiber-based foods as a part of highly recommends diet therapy. Fibers, especially water-soluble fibers, can control blood sugar levels by slowing down the digestion of food in the stomach, where fiber and food absorb water in the stomach and convert food to be more viscous. More viscous foods will slow down the process of digestion and absorption of nutrients including glucose [4]. One nutritional intervention in fulfilling fiber intake in patients with type 2 diabetes mellitus is to pay attention to the factor of the eating sequence of various types of food which can affect blood sugar levels.

Prioritizing the consumption of vegetables before carbohydrates are perhaps; be an alternative nutritional education that is easy for people with Diabetes Mellitus in fulfilling their daily fiber needs and improving blood sugar levels[5]. The recommended fiber intake for people with diabetes is $25 \mathrm{~g} /$ day[6]. This study aimed to assess the effect of vegetables consumption before carbohydrate on fiber intake and blood sugar level of patients with type 2 Diabetes Mellitus.

\section{RESEARCH METHOD}

This was a randomized experimental study with preposttests group design. Diabetes patients who were willing to take part in the study had received an explanation of the research procedures and had signed in informed consent This research was conducted by giving treatment to subjects in the form of breakfast consisting of rice, livestock side dishes, vegetable side dishes, and veggies. The calorific value of the treatment menu is obtained from the average nutritional needs of the subjects and $20 \%$ of the composition is taken as breakfast. Nutrient composition of meals wass 387.24 calories, $18.22 \mathrm{~g}$ protein, $14.60 \mathrm{~g}$ fat, $53.14 \mathrm{~g}$ carbohydrates, and $7.07 \mathrm{~g}$ fiber. The composition of macronutrients in the test meal is $14.8 \%$ protein, $20 \%$ fat, and $64.9 \%$ carbohydrate. Subjects were divided into 3 groups, namely the treatment group (T1) vegetables were eaten before rice/carbohydrate, the treatment group (T2) vegetables were eaten with rice/carbohydrates and the control group was subject to only nutrition education related to the Diabetes Mellitus diet. The provision of intervention carried out for 10 days. Before being given an intervention, subjects were required to fast for 10 hours, then in the next morning, a blood sugar level test was taken before the intervention. After the intervention was 
given for 10 days, subjects were also required to fast for 10 hours and fasting blood sugar levels test were taken the next day as post-intervention blood sugar levels. Anthropometric

measurements carried out by researchers include weight and height. Bodyweight was measured using a digital weight scale with a precision of $0.1 \mathrm{~kg}$ and height was measured using a digital height scale with an accuracy of $0.1 \mathrm{~cm}$, both were used to calculate the Body Mass Index (BMI) and determine the nutritional needs of individual subjects. Measurement of blood sugar levels using spectrophotometry methods, carried out by analysts, while measurements of dietary fiber intake were carried out by researchers using 24hour food record and food recall methods. Fiber intake is calculated from the average intake of foods containing fiber during the study, including fiber intake outside of intervention and expressed in units of grams /day. Data were analyzed using SPSS (Statistical Package for Social Science) version 23.0 with the Wilcoxon test and Paired T-Test to determine differences in average blood sugar levels and fiber intake before and after the intervention. ANOVA (Analysis of Variance) and Kruskall Wallis tests were used to determine the effect of vegetable eating sequence interventions on fiber intake. This study has passed ethical eligibility by the Hospital Health Research Ethics Commission Dr. Moewardi Surakarta, with No. 136 / I / HREC / 2020. This study was conducted in February 2020. The populations in this study were all type 2 Diabetes Mellitus patients who met the inclusion and exclusion criteria. The inclusion criteria of the studied subjects included type 2 DM patients who received oral hypoglycemic drugs, aged 18-65 years, male or female, like to eat vegetables, doing mild physical activity. Exclusion criteria: there are complications of other diseases, microvascular / macro- vascular such as chronic kidney disease, heart disease, hyper- uricemia, difficulty chewing and swallowing, gastroenteritis, pregnancy, smoking, using supplements/herbal medicines to reduce blood sugar levels, get insulin therapy. The number of research subjects was calculated using the hypothesis testing formula in two population averages, obtained as many as 24 people including loss of follow-up, and divided into 8 people in each group.

TABLE I. TEST MEAL OF BREAKFAST COMPONENTS FOR RESEARCH PARTICIPANTS

\begin{tabular}{|l|c|}
\hline \multicolumn{1}{|c|}{ Menu order } & Amount (gram) \\
\hline Rice & 100 \\
\hline Livestock side dish & 50 \\
\hline Vegetable side dish & 50 \\
\hline Veggies & 150 \\
\hline Oil & 5 \\
\hline
\end{tabular}

\section{RESULT}

Total of 16 women and 8 men with type 2 Diabetes Mellitus who received oral blood sugar-lowering drugtherapy participated. in this study. The characteristics of research subjects can be seen in table 2 .
TABLE II. CHARACTERISTIC OF RESEARCH PARTICIPANTS

\begin{tabular}{|c|c|c|c|c|}
\hline \multirow[b]{2}{*}{ Characteristics } & \multicolumn{3}{|c|}{ Research Participants } & \multirow[b]{2}{*}{ p } \\
\hline & $\begin{array}{c}C \\
(n=8)\end{array}$ & $T 1(n=8)$ & $T 2(n=8$ & \\
\hline Age (year) & $\begin{array}{l}56.25 \pm \\
6.20\end{array}$ & $\begin{array}{c}57.25 \pm 6 \\
18\end{array}$ & $\begin{array}{c}57.75 \pm \\
7.22\end{array}$ & 0.898 \\
\hline Weight (kg) & $\begin{array}{l}67.46 \pm \\
13.29\end{array}$ & $\begin{array}{c}64.08 \pm 13 \\
.21\end{array}$ & $\begin{array}{c}56.56 \pm \\
10.37\end{array}$ & 0.220 \\
\hline Height $(\mathrm{cm})$ & $\begin{array}{l}158.38 \\
\pm 6.43\end{array}$ & $\begin{array}{c}153.03 \pm 5 \\
.68\end{array}$ & $\begin{array}{c}150.5 \pm \\
3.56\end{array}$ & 0.024 \\
\hline BMI (kg/m2) & $\begin{array}{l}26.55 \pm \\
4.42\end{array}$ & $\begin{array}{c}27.38 \pm 5 \\
85\end{array}$ & $\begin{array}{c}24.23 \pm \\
3.8\end{array}$ & 0.409 \\
\hline $\begin{array}{l}\text { Duration of DM } \\
\text { illness (year) }\end{array}$ & $\begin{array}{l}3.38 \pm 1 \\
59\end{array}$ & $\begin{array}{c}3.50 \pm \\
2.67\end{array}$ & $\begin{array}{c}5.88 \pm 4 \\
15\end{array}$ & 0.195 \\
\hline $\begin{array}{l}\text { Gender }(\%) \\
\text { Male } \\
\text { Female }\end{array}$ & $\begin{array}{l}4(16.7) \\
4(16.7)\end{array}$ & $\begin{array}{l}3(12.5) \\
5(20.8)\end{array}$ & $\begin{array}{l}1(4.2) \\
7(29.2)\end{array}$ & 0.269 \\
\hline $\begin{array}{l}\text { Nutrition Status } \\
\text { Normal weight } \\
\text { Overweight } \\
\text { Obese }\end{array}$ & $\begin{array}{l}2(8.3) \\
4(16.7) \\
2(8.3)\end{array}$ & $\begin{array}{c}3(12.5) \\
4(16.7) \\
1(4.2)\end{array}$ & $\begin{array}{l}4(16.7) \\
4(16.7)\end{array}$ & 0.615 \\
\hline
\end{tabular}

a. control group, T1: vegetable consumption before carbohydrates, T2: vegetable consumption after carbohydrates. Data were presented as mean $\pm \mathrm{SD}$ and significant difference with $\mathrm{p}<0.05$.

\section{A. The Effect of Vegetable Eating Sequence on Increasing Fiber Intake}

The effect of vegetable eating sequences on increasing fiber intake can be seen in table 2. The average fiber intake of the three treatment groups was $6.63 \pm 1.18$ grams/day in the control group, $9.56 \pm 2.52$ grams /day in the P1 group, and

$8.71 \pm 1.60 \mathrm{gram} /$ day in group 2 . After the intervention was given in the form of eating vegetables with carbohydrates, it was seen that the increases in fiber intake after the intervention was in group P1 (sequence of eating vegetables before carbohydrate) and group P2 (sequence of eating vegetables with carbohydrates), with an average of $12.24 \pm$

2.97 respectively gram/day and $9.04 \pm 1.89$ gram/day. Significantly, the difference in mean fiber intake was shown by the P1 group (vegetable eating sequence before carbohydrate $)(p=0.012)$. Fiber intake in the control group decreased by $-0.4 \pm 1.25$ grams, while the increase in fiber intake in the P1 and P2 groups was $2.67 \pm 0.9$ and $0.29 \pm$ 0.59 grams, respectively. Total fiber intake in each group is less than the recommended amount, where the recommended consumption of fiber. grams/day. Changes in fiber intake in the P1 group increased if it's compared with the other two groups and because the study subjects prioritized eating vegetables before other test meal components such as rice and side dishes. grams/day. Changes in fiber intake in the P1 group increased if it's compared with the other two groups and because the study subjects prioritized eating vegetables before other test meal components such as rice and side dishes.

\section{B. The Effect of Vegetable Eating Sequence with Carbohydrates on Blood Sugar Levels}

The effect of vegetable eating sequence on blood sugar levels can be seen in Table 2. The highest fasting blood sugar levels before the intervention were shown by the $\mathrm{P} 2$ group that is $167 \pm 98.70 \mathrm{mg} / \mathrm{dl}$, then $\mathrm{P} 1$ and control respectively 
$148.88 \pm 30.79 \mathrm{mg} / \mathrm{dl}$ and $148.88 \pm 30.79 \mathrm{mg} / \mathrm{dl}$. After the intervention, there was a decrease in fasting blood sugar levels in all groups. The mean decreases in blood sugar levels were greatest in the P1 group $(-48.00 \pm 23.96) \mathrm{mg} / \mathrm{dl}$. The mean decreases in blood sugar levels in the P1 group (vegetable eating sequence before carbohydrate) and control $(\mathrm{K})$ were more significant than the other two groups $(\mathrm{p}=0.010)$. (Table 3$)$.

TABLE III. TOTAL AVERAGE OF FIBER INTAKE AND BLOOD SUGAR LEVELS AMONG GROUPS

\begin{tabular}{|c|c|c|c|c|c|c|c|c|c|}
\hline \multirow{3}{*}{$\begin{array}{c}\text { variab } \\
\text { le }\end{array}$} & \multicolumn{9}{|c|}{ Research participant } \\
\hline & \multicolumn{3}{|c|}{$\mathrm{C}$} & \multicolumn{3}{|c|}{ T1 } & \multicolumn{3}{|c|}{$\mathrm{T} 2$} \\
\hline & $\begin{array}{l}\begin{array}{l}B \\
(n= \\
8)\end{array} \\
\text { (a) }\end{array}$ & $\begin{array}{l}A \\
(n=8 \\
)\end{array}$ & $\mathrm{p}$ & $\begin{array}{l}\begin{array}{l}B \\
(n=8\end{array} \\
)\end{array}$ & $\begin{array}{l}A \\
n=8 \\
)\end{array}$ & $\mathrm{p}$ & $\begin{array}{l}\text { B } \\
(\mathrm{n} \\
=8 \\
)\end{array}$ & $\begin{array}{l}\mathrm{A} \\
(\mathrm{n}= \\
8)\end{array}$ & $\mathrm{p}$ \\
\hline $\begin{array}{l}\text { Fiber } \\
\text { intake } \\
\text { (g/day } \\
\text { ) }\end{array}$ & $\begin{array}{c}6.6 \\
3 \pm \\
1.1 \\
8\end{array}$ & $\begin{array}{l}6.22 \\
\pm \\
1.90\end{array}$ & $\begin{array}{l}0.38 \\
9\end{array}$ & $\begin{array}{c}9.56 \\
\pm \\
2.52\end{array}$ & $\begin{array}{c}12.2 \\
4 \pm \\
2.97\end{array}$ & $\begin{array}{c}0.01 \\
2\end{array}$ & $\begin{array}{l}8.7 \\
1 \pm \\
1.6 \\
0\end{array}$ & $\begin{array}{c}9.0 \\
4 \pm \\
1.8 \\
9\end{array}$ & 0.160 \\
\hline $\begin{array}{l}\text { Eastin } \\
\text { g } \\
\text { blood } \\
\text { sugar } \\
\text { levels } \\
\text { (mg/dl } \\
\text { ) }\end{array}$ & $\begin{array}{l}148 \\
.88 \\
\pm \\
30 . \\
79\end{array}$ & $\begin{array}{l}94.0 \\
\pm \\
10.9 \\
0\end{array}$ & $\begin{array}{l}0.39 \\
6\end{array}$ & $\begin{array}{l}148 . \\
88 \pm \\
30.7 \\
9\end{array}$ & $\begin{array}{l}100 . \\
88 \\
\pm 14 \\
.59\end{array}$ & $\begin{array}{l}0.00 \\
1\end{array}$ & $\begin{array}{l}16 \\
7 \pm \\
98 . \\
70\end{array}$ & $\begin{array}{l}137 \\
.38 \\
\pm \\
51 . \\
42\end{array}$ & 0.145 \\
\hline
\end{tabular}

C: control group, T1: vegetable consumption before carbohydrates, T2 vegetable consumption after carbohydrates. B: before intervention, A: after intervention. Data were presented as mean \pm SD and significant difference with $\mathrm{p}<0.05 . \mathrm{SD}=$ standard deviation

TABLE IV. CHANGES IN FIBER INTAKE AND INTERGROUP's BLOOD SUGAR LEVELS AFTER INTERVENTION

\begin{tabular}{|l|l|l|l|l|}
\hline \multicolumn{1}{|c|}{$\begin{array}{c}\text { Groups } \\
(\mathrm{n}=8)\end{array}$} & $\begin{array}{c}\text { Fiber intake } \\
\text { change (gr) }\end{array}$ & $\mathrm{p}$ & $\begin{array}{c}\text { Fasting blood } \\
\text { sugar levels } \\
\text { change (mg/dl) }\end{array}$ & $\mathrm{p}$ \\
\hline $\mathrm{C}$ & $-0.4 \pm 1.25$ & & $-9.25 \pm 32.15$ & \\
$\mathrm{~T} 1$ & $2.67 \pm 0.9$ & $<0.001$ & $-48.00 \pm 23.96$ & 0.010 \\
\hline $\mathrm{C}$ & $-0.4 \pm 1.25$ & & $-9.25 \pm 32.15$ & \\
$\mathrm{~T} 2$ & $0.29 \pm 0.59$ & 0.326 & $-29.63 \pm 51.16$ & 0.065 \\
\hline $\mathrm{T} 1$ & $2.67 \pm 0.90$ & & $-48.00 \pm 23.96$ & \\
$\mathrm{~T} 2$ & $0.29 \pm 0.59$ & $<0.001$ & $-29.63 \pm 51.16$ & 0.234 \\
\hline
\end{tabular}

C: control group, T1: veggies first before carbohydrate sequence treatment, T2: veggies with carbohydrate sequence treatment. Data were presented as mean $\pm \mathrm{SD}$ and significant difference with $\mathrm{p}<0.05, \mathrm{SD}=$ standard deviation

\section{DISCUSSION}

The management of diet therapy is one of the pillars in controlling blood sugar levels of patients with type 2 diabetes mellitus. The regulation of eating in diabetes has so far been focused on 3J guidelines, namely schedule (jadwal), type (jenis), and amount (jumlah) [3]. These three things can be combined with a method of eating by paying attention to the eating sequence of various types of food. This study aimed to analyze the effect of the sequence of eating vegetables with carbohydrates with the treatment of eating vegetables before carbohydrates and eating vegetables together with carbohydrates. The results of this study stated that consuming vegetables before carbohydrates were statistically significant in increasing fiber intake and decreasing blood sugar levels and in line with the results of previous studies [7][8]. Fiber intake increases in the treatment of eating vegetables before carbohydrates, this is because vegetables consumed earlier than other types of food contribute to a greater amount of fiber intake, although other food components also contain fiber, vegetables are the main source of fiber in the food group. Although fiber intake in all treatment groups was still less than the adequacy of the recommended fiber intake, through intervention prioritizing the intake of vegetables before carbohydrates and other foods had a positive impact on increasing the amount of fiber intake. The mechanism of fiber can help reduce blood glucose levels, which is food fibers, especially water-soluble fibers can form more viscous food (forming a gel). More viscous foods will slow the process of emptying the stomach and cause food digestion to slow down. This slow digestion causes a decrease in the absorption of nutrients including glucose, resulting in controlled blood sugar levels [4][9]. In the next mechanism, undigested fiber will enter the large intestine and will be fermented by bacteria into Short-Chain Fatty Acid (SCFA). The formation of this SCFA induces the secretion of the hormone GLP-1 (Glucagon-Like Peptide-1), GIP (Gastric Inhibitory Polypeptide), and PYY (Peptide YY) which will increase insulin sensitivity and ultimately cause a decrease in blood glucose levels [10][11]

Most of the research subjects have understood the important role of fiber from vegetables as nutritional therapy that can control blood sugar levels but from the results of food records and interviews with food recall 24 hours, vegetable intake at the time other than providing intervention time is less than the vegetables served by researchers $(<150$ grams), even though nutritional education has been given about eating dose outside of the intervention. Vegetable consumption of at least 150 grams per day can improve blood sugar control and HbA1c levels in patients with type 2 DM [12]. This study also proved that the order of eating vegetables before carbohydrates also improved blood sugar control, evidenced by a decrease in fasting blood sugar levels in all treatment groups. Only a significant decrease was found in the control group with P1 with $\mathrm{p}=0.010$. This is in line with previous research which states that intake of vegetables before carbohydrates improves blood sugar and prevents fluctuations in an uncontrolled increase in blood sugar [13]. The method of sequencing vegetables before carbohydrates can be used as dietary advice in patients with type 2 diabetes in eating arrangements, so it is not only based on the type, schedule, or amount of energy. Fiber intake of all research subjects is still low and needs to be educated repeatedly about the importance of consuming fiber intake to control blood sugar levels.

\section{CONCLUSION}

Our results indicate that vegetables consumption before carbohydrates improves daily fiber intake and blood sugar levels in patients with type 2 diabetes mellitus. This finding suggests that nutrition therapy through food sequence can be added to the existing diabetes diet in order to achieve normal glycemic index. 


\section{ACKNOWLEDGMENT}

Researcher's gratitude spoken for the Head of Manyaran Semarang Health Center and the medical team, as well as the respondents who have agreed to participate in this study.

\section{REFERENCES}

[1] R. I. Kemenkes, "Hasil utama RISKESDAS 2018," Online http//www. depkes. go. id/resources/download/infoterkini/materi_rakorpop_2018/Hasil\% 20Riskesdas, vol. 202018, 2018.

[2] R. A. Roth, Nutrition \& diet therapy. Cengage Learning, 2013.

[3] P. E. Indonesia, "Konsensus pengelolaan dan pencegahan diabetes melitus tipe 2 di Indonesia 2015," PB PERKENI, 2015.

[4] L. K. Mahan and J. L. Raymond, Krause's Food \& the Nutrition Care Process, Mea Edition E-Book. Elsevier, 2016.

[5] A. P. Shukla, R. G. Iliescu, C. E. Thomas, and L. J. Aronne, "Food order has a significant impact on postprandial glucose and insulin levels," Diabetes Care, vol. 38, no. 7, pp. e98-e99, 2015.

[6] P. D. A. N. Pencegahan and D. I. Indonesia, Pengelolaan dan pencegahan diabetes melitus tipe 2 di indonesia 2015. 2015.
[7] S. Imai, M. Fukui, and S. Kajiyama, "Effect of eating vegetables before carbohydrates on glucose excursions in patients with type 2 diabetes," vol. 54, no. 1, pp. 7-11, 2014.

[8] K. Clinic, "Eating vegetables before carbohydrates improves postprandial glucose excursions," pp. 370-372, 2012.

[9] [9] A. K. Hervik, "The Role of Fiber in Energy Balance," vol. 2019, 2019.

[10] M. O. Weickert and A. F. H. Pfeiffer, "Impact of dietary fiber consumption on insulin resistance and the prevention of type 2 diabetes," J. Nutr., vol. 148, no. 1, pp. 7-12, 2018.

[11] A. Woting and M. Blaut, "The Intestinal Microbiota in Metabolic Disease," 2016.

[12] K. Takahashi et al., "Effects of total and green vegetable intakes on glycated hemoglobin A1c and triglycerides in elderly patients with type 2 diabetes mellitus: The Japanese Elderly Intervention Trial," Geriatr. Gerontol. Int., vol. 12, pp. 50-58, 2012.

[13] S. Imai et al., "Original Article A simple meal plan of " eating vegetables before carbohydrate' was more effective for achieving glycemic control than an exchange - based meal plan in Japanese patients with type 2 diabetes," vol. 20, no. April 2010, pp. 161-168, 2011. 